\title{
OPEN The Effect of CaO Catalyst Mass from Golden Snail Shell (Pomacea Canaliculata Lamarck) on Transesterification Reaction
}

Fachtur Rahman ${ }^{\mathrm{a}}$ and Siti Rodiah ${ }^{\mathrm{b} *}$

Abstract. Biodiesel derived from waste encourages the development of environment-friendly alternative energy. One of the wastes that can be used as biodiesel is waste cooking oil. Biodiesel from waste cooking oil has some advantages such as non-toxic, less Carbon monoxide (CO), and environmentfriendly. The produce of biodiesel from waste cooking oil was through transesterification reaction using $\mathrm{CaO}$ catalyst derived from golden snail shell. This study aimed to determine the optimum amount of catalyst that produced the highest yield. In this study, methanol was used as solvent by the molar ratio of methanol/waste cooking oil of $30: 1$, reaction temperature of $65^{\circ} \mathrm{C}$, reaction time for 2 hour, and variations of amount catalyst 3\%, 5\% and $7 \%$ by weight waste cooking oil. Biodiesel was analyzed by Gas Chromatography-Mass Spectroscopy showed that the highest yield achieved using $7 \%$ catalyst amounts was $93.28 \%$.

Keywords: biodiesel, waste cooking oil, $\mathrm{CaO}$ catalyst, golden snail shell, transesterification reaction 


\section{Introduction}

Waste cooking oil contains high free fatty acids and carcinogenic compounds (cancer) after used many times [1] produced free radical content that could attack cells in the body causing cancer. The waste cooking oil is very potentially polluting the environment, including lowering air quality, disrupting the balance of water biota and causing a foul odor due to bacterial degradation [2], [3].

One of the ways to reduce the environmental impact from waste cooking oil was utilizing it as biodiesel raw material. Biodiesel is biodegradable alternative fuel derived from acids-vegetable and animal fatty acids [4]. Biodiesel is produced via transesterification reaction generally using hydroxide-base catalysts such as $\mathrm{NaOH}$, and $\mathrm{KOH}$. Alkaline hydroxide is a homogeneous catalyst that can cause the formation of soap in biodiesel production [5]. These problems could be addressed by the use of heterogeneous catalysts.

Heterogeneous catalysts have several advantages, such as non-toxic, non-corrosive,

\section{Experimental}

\section{Catalyst preparation}

The golden snail shell was cleaned by removing meat from the shell. The shells were crushed and washed to remove impurities. Furthermore, the shell was dried in the oven at $110^{\circ} \mathrm{C}$ for 24 hours followed by calcined at $900{ }^{\circ} \mathrm{C}$ for 2 hours to obtain the shell powder [9]. In order to determine the presence of $\mathrm{CaO}$ functional group and the crystalline phase, the catalyst was analyzed using FT-IR-ATR Bruker Alpha equipped with diamond crystal.

\section{Transesterification Reaction}

Transesterification reactions were carried out in 3 neck flasks equipped with a condenser and a magnetic stirrer. The reaction was set up with variations of catalyst $3 \%, 5 \%$ and $7 \%$ by weight waste cooking oil, molar ratio of methanol/waste cooking oil 30:1 at $65^{\circ} \mathrm{C}$ for 2 hours. Product, catalyst, and by product was separated in separating funnel by adding $\mathrm{n}$-hexane to extract biodiesel as main product. Biodiesel dissolved in $n$-hexane were obtained in the environment friendly, reuse-able, easily separated, can be made from natural materials and waste [6]. Some research reported that waste material could be utilized as a catalyst. Golden snail shell waste material was a potential resource of $\mathrm{CaO}$ catalyst for biodiesel production [7] that reached $94,43 \%$ of biodiesel yield [8]. The presence of $\mathrm{CaO}$ groups was investigated through Fourier Transform Infrared analysis.

Modified calcined golden snail shell with fly ash as a catalyst [9] has been investigated that 3\% (by weight of oil) of unmodified calcined golden snail shell had good performances to convert waste cooking oil become biodiesel rather than modified catalyst. This study had not investigated the optimum mass which produced high yield biodiesel. Based on this research, the calcined golden snail shell used as catalyst for the production of biodiesel from oil, with variations in the number of $\mathrm{CaO}$ catalysts. The purpose of the study is to determine the number of optimum catalysts that yield the highest yield that analyzed using gas chromatography.

upper layer, meanwhile the catalyst, methanol, and glycerol as by-product were at under layer. Biodiesel was analyzed with Gas Chromatography-MS to determine the yield.

\section{Characterization of Biodiesel}

Density of biodiesel

Procedures used to determine biodiesel density refers to ASTM D 1298-99. Biodiesel density was calculated using Eq. 1.

Density $=\frac{m b-m a}{V}$

$$
\begin{aligned}
& \mathrm{ma}=\text { Mass of empty pycnometer }(\mathrm{g}) \\
& \mathrm{mb}=\text { Mass of biodiesel in pycnometer }(\mathrm{g}) \\
& \mathrm{v}=\text { Volume Pycnometer }(\mathrm{ml})
\end{aligned}
$$

\section{Viscosity of biodiesel}

Preheat biodiesel at $40{ }^{\circ} \mathrm{C}$ and was included in the Ostwald viscometer tube on the sample charging side as much as $5 \mathrm{~mL}$ and the flow rate holes were closed. Open the lid of the flow rate hole and note the 
biodiesel time to reach the impressions mark. Viscosity can be determined by following formula.

$$
\text { Viscosity }=\eta \times \frac{d 2-t 2}{d 1-t 1}
$$

\section{Results and Discussion}

As shown in Figure 1, appearing peaks in area of $3645 \mathrm{~cm}^{-1}$ indicated $\mathrm{OH}$ absorption. The presence of $\mathrm{OH}$ was shown appearing peaks in area of $4000-$ $3500 \mathrm{~cm}^{-1}$ [10]. The $\mathrm{OH}$ functional group derived from $\mathrm{Ca}(\mathrm{OH})_{2}$ which was formed during the dissolution of $\mathrm{CaO}$. The $\mathrm{CaO}$ absorption appeared under $600 \mathrm{~cm}^{-1}$

$\eta=$ Viscosity of aquadest in $40{ }^{\circ} \mathrm{C}(0,6529 \mathrm{Cst})$
$\mathrm{d} 1=$ Density of aquadest in $40{ }^{\circ} \mathrm{C}(0,993 \mathrm{~g} / \mathrm{ml})$
$\mathrm{t} 1=$ time for flow (aquadest) $(\mathrm{s})$
$\mathrm{d} 2=$ Density of biodiesel in $40{ }^{\circ} \mathrm{C}(\mathrm{g} / \mathrm{ml})$
$\mathrm{t} 2=$ time for flow (biodiesel) $(\mathrm{s})$

[4], which was seen at $454 \mathrm{~cm}^{-1}$ in current study. Furthermore, the absorption of $\mathrm{CaCO}_{3}$ did not appear in the wavenumber of $1800-800 \mathrm{~cm}^{-1}$, showed that the $\mathrm{CaCO}_{3}$ from snail shell has been perfectly decomposed to form $\mathrm{CaO}$, see Equation 3 [9].

$$
\mathrm{CaCO} 3(\mathrm{~s}) \rightarrow \mathrm{CaO}(\mathrm{s})+\mathrm{CO} 2(\mathrm{~g})
$$

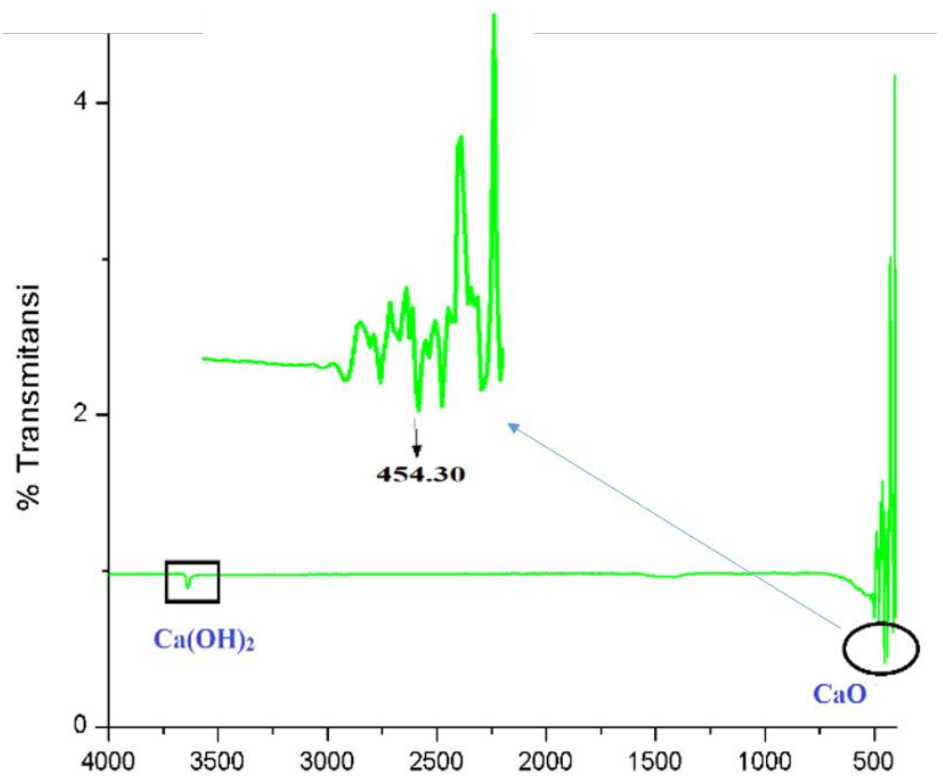

Figure 1. FTIR Spectrum of CaO Catalyst from golden snail shell

\section{Transesterification Reaction}

$\mathrm{CaO}$ catalyst from golden snail shell applied to transesterification reaction to convert used cooking oil become biodiesel. The highest content of fatty acids in used cooking oil is palmitic acid, which has chain of fatty acids in clusters R1, R2, and R3, so that to convert palmitic acid become methyl ester (biodiesel) was needed 3 molecules of alcohol.
Transesterification reaction takes place in several stages as follows:

$$
\mathrm{ROH}+\mathrm{CaO} \rightarrow \mathrm{CaOH}^{+}+\mathrm{RO}^{-}
$$

The transesterification reaction began with the formation of alkoxy and protonation of the catalyst after reaction of $\mathrm{CaO}$ catalysts and (equation 4). The lone pair on the $O$ atom of the catalyst pulls the $\mathrm{H}$ atom from the alcohol, thus the catalyst was protonated and the alcohol becomes an alkoxy ion. The nucleophilic alkoxy then attacked the carbonyl 
group (electrophilic) in triglycerides to form intermediate molecules then rearranged the atoms to produce methyl ester (biodiesel) and diglyceride anions (see Equation 5). Furthermore, alkoxy attacked other carbonyl groups in the diglyceride molecules thereby forming a single methyl ester and monoglyceride. The reaction continued to form three molecules of methyl ester and one molecule of glycerol (equation 6

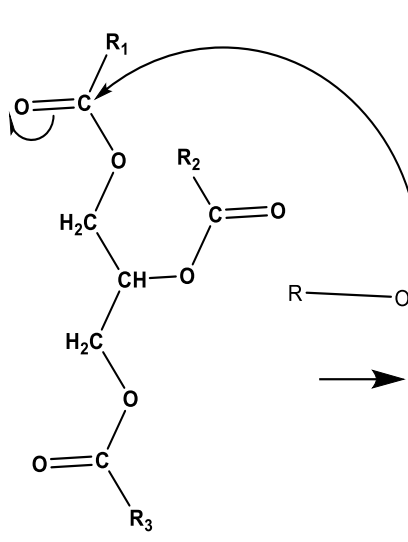

Tryglyseride

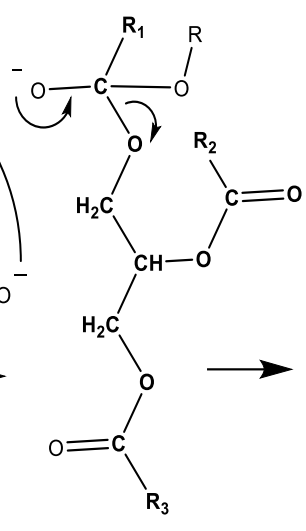

intermediate

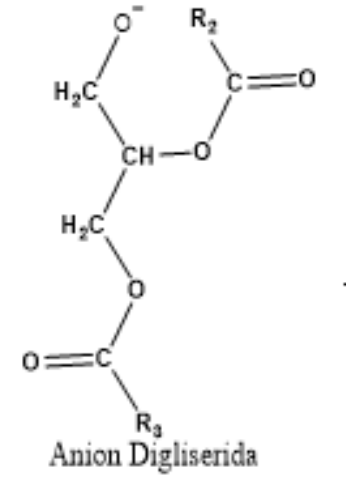

$+\quad \|_{\mathrm{C}_{1}}^{\mathrm{O}}>^{\mathrm{R}}$

Metil Ester (Biodiesel)

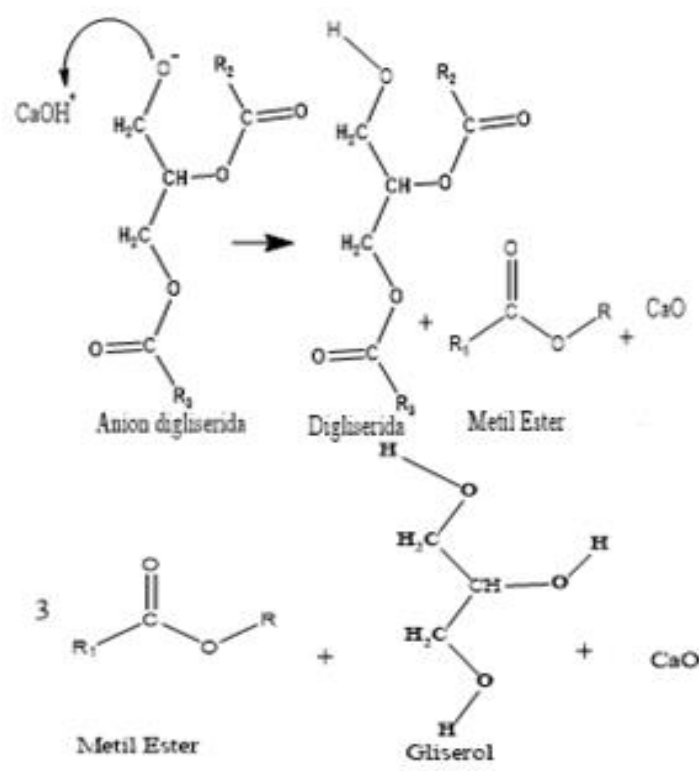

(5)

(6)

Figure 3 showed the pattern of catalyst mass to biodiesel yield. The more increase of catalytic mass, the more increase biodiesel yield. The high amount of $\mathrm{CaO}$ provided more base sites which played an important role in the reaction. 


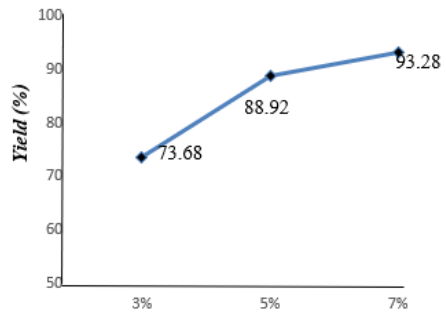

Figure 3. The pattern of catalyst mass to biodiesel yield

\section{Characterization of Biodiesel}

Density and viscosity of biodiesel obtained was compared to the quality of biodiesel based on Nasional Standard of Indonesia (SNI 7128:2015). Density and viscosity of biodiesel with variations of catalysts mass such as $3 \%, 5 \%$, and $7 \%$ were shown in Figure $4 \mathrm{a}$ and Figure $4 \mathrm{~b}$ respectively. Biodiesel density and viscosity in this study close to the SNI SNI

\section{References}

[1] H. Adhari, Yusnimar, and S. P. Utami, "Pemanfaatan Minyak Jelantah Menjadi Biodiesel Dengan Katalis ZnO Presipitan Zinc Karbonat : Pengaruh Waktu Reaksi dan Jumlah Katalis," vol. 3, no. 2, pp. 1-7, 2016.

[2] P. M. Anisah, D. Suwandi, M. Si, and E. A. M. Eng, "Pengaruh Waktu Transesterifikasi terhadap Konversi Minyak Jelantah menjadi Biodiesel," vol. 5, no. 1, pp. 916-922, 2018.

[3] wiwik indrawati Mudatsir, "Pengaruh Penambahan $\mathrm{NaOH}$ dan Metanol terhadap Produk Biodiesel dari Minyak Goreng Bekas (Jelantah) dengan Metode Transesterifikasi," no. November, pp. 9-16, 2016.

[4] M. Said, "Katalis Basa Heterogen Campuran $\mathrm{CaO} \& \mathrm{SrO}$ pada Reaksi Transesterifikasi Minyak Kelapa Sawit," pp. 26-27, 2011.

[5] Y. T. Rahkadima et al., "Produksi biodiesel dari minyak jelantah menggunakan katalis kalsium oksida," vol. 2, no. 1, pp. 44-48, 2016.

[6] N. Hidayati, T. S. Ariyanto, P. Studi, T. Kimia, and U. M. Surakarta, "Transesterifikasi Minyak Goreng Bekas menjadi Biodiesel dengan
$7182: 2015$ namely $0.85-0.89 \mathrm{~g} / \mathrm{cm}^{3}$ and $2.3-6.0$ $\mathrm{mm}^{2} / \mathrm{s}$.
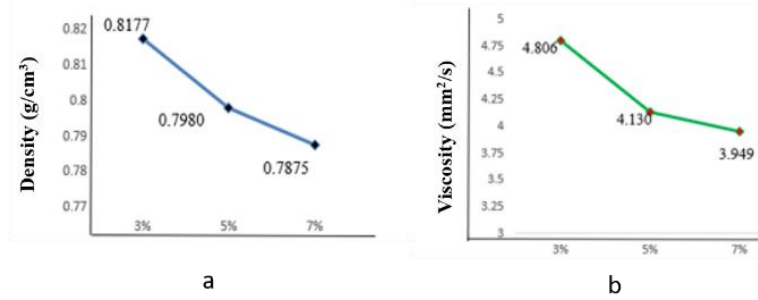

Figure 4. The of catalyst mass to: a) density and b) viscosity

\section{Conclusion}

Based on the research results that the $\mathrm{CaO}$ catalysts of the snail shell showed good catalytic activity for the transesterification reaction. The highest yield achieved using $7 \%$ catalyst amounts was $93.28 \%$.

Katalis Kalsium Oksida," vol. 1, no. 1, pp. 1-5, 2017.

[7] O. L. Ki, S. Ismadji, A. Ayucitra, F. E. Soetaredjo, and Y. Yulia, "Use of apple snail ( Pomacea sp .) shell as a catalyst for biodiesel production : full factorial design optimisation," pp. 351367.

[8] H. S. Prastyo, Y. Y. Margaretha, and A. Ayucitra, "Prosiding Seminar Nasional Fundamental dan Aplikasi Transesterifikasi Minyak Kelapa Sawit dengan Menggunakan Katalis Padat dari Cangkang Keong Mas (Pomacea s p.)," no. Xxx, 2011.

[9] S. Rodiah, D. Erviana, F. Rahman, and A. W. Budaya, "Modified CaO Catalyst from Golden Snail Shell (Pomacea canaliculata) for Transesterification Reaction of Used Cooking Oil," Al-Kimia, vol. 8, no. 1, pp. 83-92, 2020.

[10]

D. Prasetyoko, "Penggunaan Cangkang Bekicot sebagai Katalis untuk Reaksi Transesterifikasi Refined Palm Oil," no. January, 2014. 